ISSN : 2303-1514 | E-ISSN : 2598-5949

\title{
IMPROVING INTEGRATED THEMATIC LEARNING PROCESS USING SCIENTIFIC APPROACH AT GRADE 3 ELEMENTARY SCHOOL
}

\author{
Zahratul Amalia ${ }^{1}$, Riza Safriani ${ }^{2}$, Delismita Pusra ${ }^{3}$ \\ ${ }^{1,2}$ Universitas Negeri Padang, Padang, Indonesia \\ ${ }^{3}$ SDN 20 Indarung, Padang, Indonesia \\ lamaliazahratul11@gmail.com, ${ }^{2}$ rizasafriani@gmail.com, ${ }^{3}$ delismitapusra70@gmail.com
PENINGKATAN PROSES PEMBELAJARAN TEMATIK TERPADU MENGGUNAKAN PENDEKATAN SAINTIFIK SISWA KELAS III SEKOLAH DASAR

\begin{tabular}{|c|c|}
\hline ARTICLE HISTORY & ABSTRACT \\
\hline $\begin{array}{l}\text { Submitted: } \\
\text { 19 Juli } 2021 \\
19^{\text {th }} \text { July } 2021\end{array}$ & $\begin{array}{l}\text { Abstract: The purpose of this study was to improve integrated thematic learning process } \\
\text { through scientific approach at grade } 3 \text { elementary school. The subjects of this study were } \\
\text { researchers as the teachers, and } 22 \text { students. This study applied PTK research. This study } \\
\text { utilized a qualitative and quantitative approach. The results showed an increase in: (a) the } \\
\text { average value of RPP in cycle I for } 98 \% \text { (A) and } 100 \%(A) \text { in cycle II, (b) the result of the } \\
\text { learning process from teachers' aspects in cycle I was } 80 \%(B) \text { and in cycle } 2 \text { was } 95 \%(A),(c) \\
\text { the students' aspects in cycle } 1 \text { was } 51.59 \%(D) \text { and in cycle II was } 86.59 \%(A) \text {. } \\
\text { Keywords: learning process, scientific approach }\end{array}$ \\
\hline $\begin{array}{l}\text { Accepted: } \\
\text { 04 Agustus } 2021 \\
04^{\text {th }} \text { August } 2021\end{array}$ & $\begin{array}{l}\text { Abstrak: Penelitian ini bertujuan mendeskripsikan bagaimana peningkatan proses } \\
\text { pembelajaran tematik terpadu menggunakan pendekatan saintifik siswa kelas III SDN } 17 \\
\text { Manggis Ganting Kota Bukittinggi. Jenis penelitian ini adalah PTK dengan pendekatan } \\
\text { kualitatif dan kuantitatif. Prosedur penelitian meliputi perencanaan, pelaksanaan, } \\
\text { pengamatan, dan refleksi. Subjek penelitian adalah peneliti sebagai guru dan } 22 \text { orang siswa. } \\
\text { Teknik pengumpulan data yaitu observasi dan tes. Hasil penelitian RPP siklus I } 98 \% \text { (A), siklus } \\
\text { II 100\% (A). Hasil pelaksanaan pembelajaran aspek guru siklus I } 80 \% \text { (B), siklus II meningkat } \\
\text { menjadi 95\% (A) dan aspek siswa siklus I } 51.59 \% \text { (D), siklus II meningkat menjadi } 86.59 \text { (A). } \\
\text { Dengan demikian, pendekatan saintifik dapat meningkatkan proses pembelajaran tematik } \\
\text { terpadu siswa kelas III SDN } 17 \text { Manggis Ganting. }\end{array}$ \\
\hline
\end{tabular}

Published:

27 Agustus 2021

$27^{\text {th }}$ August 2021

Kata Kunci: proses pembelajaran, pendekatan saintifik

\section{CITATION}

Amalia, Z., Safriani, R., \& Pusra, D. (2021). Improving Integrated Thematic Learning Process Using Scientific Approach at Grade 3 Elementary School. Primary: Jurnal Pendidikan Guru Sekolah Dasar, 10 (4), 1046-1053. DOI: http://dx.doi.org/10.33578/jpfkip.v10i4.8470 .

\section{PENDAHULUAN}

Kurikulum dalam Undang-Undang No. 20 Tahun 2003 di bagian Bab I Pasal 1 ayat 19 adalah seperangkat rencana dan pengaturan mengenai tujuan, isi, dan bahan pelajaran serta cara yang digunakan sebagai pedoman penyelenggaraan kegiatan pembelajaran untuk mencapai tujuan pendidikan tertentu. Pada saat ini, sekolah dasar telah menggunakan kurikulum 2013, yaitu menggunakan pembelajaran tematik terpadu. Pembelajaran tematik terpadu menggunakan tema sebagai pemersatu kegiatan pembelajaran yang memadukan beberapa muatan pelajaran sekaligus dalam satu kali tatap muka, untuk memberikan pengalaman yang bermakna bagi siswa, karena siswa dalam memahami berbagai konsep yang 
mereka pelajari selalu melalui pengalaman langsung dan menghubungkannya dengan konsep lain yang telah dikuasainya. Rusman (2015) juga menjelaskan bahawa tematik terpadu merupakan pembelajaran terintegrasi yang merupakan suatu sistem pembelajaran yang memungkinkan siswa, baik secara individual maupun kelompok, aktif menggali dan menemukan konsep serta prinsip-prinsip keilmuan secara holistik, bermakna, dan autentik.

Proses pembelajaran kurikulum 2013 di sekolah dasar diperuntukkan menghasilkan siswa yang produktif, kreatif, inovatif, dan efektif melalui penguatan sikap (tahu mengapa), keterampilan (tahu bagaimana), dan pengetahuan (tahu apa) yang terintegrasi. Hal ini didasari oleh adanya kesadaran bahwa perkembangan kehidupan dan ilmu pengetahuan abad ke-21, telah terjadi pergeseran ciri dibanding dengan abad sebelumnya. Sejumlah ciri abad ke-21 tersebut adalah bahwa abad ke-21 merupakan abad informasi, komputasi, otomasi, dan komunikasi. Hal inilah yang diantisipasi pada kurikulum 2013 (Pahrudin, 2019). Dalam praktiknya, kurikulum 2013 harus diimplementasikan melalui pembelajaran berbasis aktivitas yang berbasis pendekatan ilmiah. Hal ini senada dengan apa yang dinyatakan dalam Permendikbud Nomor 65 tentang standar proses pendidikan bahwa pembelajaran pada kurikulum 2013 berbasis proses sebagai penguatan penggunaan pendekatan ilmiah.

Pendekatan ilmiah dapat dikatakan sebagai proses pembelajaran yang mengarahkan siswa untuk menyelesaikan masalah melalui kegiatan perencanaan yang matang, pengumpulan data yang cermat dan analisis data yang teliti untuk menghasilkan sebuah simpulan. Oleh karena itu, siswa harus dibina kepekaannya terhadap peristiwa, ditingkatkan kemampuannya dalam mengajukan pertanyaan, dilatih ketelitiaanya dalam mengumpulkan data, dikembangkan kecermatannya dalam mengolah data untuk menjawab pertanyaan, serta dipandu dalam membuat simpulan sebagai jawaban atas pertanyaan yang diajukannya. Sehingga dalam proses pembelajaran (1) guru dituntut untuk lebih kreatif dan inovatif dalam memotivasi siswa melakukan pengamatan melalui kegiatan: melihat, menyimak, mendengar dan membaca, (2) guru juga harus memberikan dorongan kepada siswa agar dapat mengajukan pertanyaan-pertanyaan yang berhubungan dengan hasil pengamatan, (3) guru dituntut untuk memberikan motivasi kepada siswa dalam mengumpulkan informasi/mencoba dari apa yang sudah diamati, (4) dalam proses pembelajaran guru diharapkan dapat memandu pengolahan informasi yang dikumpulkan siswa dari hasil pengamatannya, (5) guru diharapkan lebih membimbing siswa dalam proses penalaran yang dilakukan siswa dari hasil yang diamati, (6) setelah itu guru harus membimbing siswa untuk menyimpulkan atau mengkomunikasikan hasil dari pengamatan siswa. Sebelum pelaksanaan pembelajaran, guru juga dituntut/ harus mampu membuat Rencana Pelaksanaan Pembelajaran (RPP) karena RPP merupakan program yang dipersiapkan untuk proses/ pelaksanaan pembelajaran di kelas, seperti yang dijelaskan oleh Kemendikbud (2013), Rencana Pelaksanaan Pembelajaran (RPP) merupakan suatu rencana kegiatan pembelajaran tatap muka untuk satu pertemuan atau lebih, RPP berkembang dari silabus untuk lebih mengarahkan kegiatan pembelajaran peserta didik untuk mencapai Kompetensi Dasar.

Namun, berdasarkan hasil pengamatan proses pembelajaran yang dilakukan di kelas III Sekolah Dasar pada tanggal 13 Januari 2021 pada Tema 5 Subtema 2 Pembelajaran 3, dengan muatan pelajaran Bahasa Indonesia, SBdP dan Matematika. Diperoleh untuk penilaian RPP sebesar $71 \%$, penilaian aspek guru $56 \%$ dan aspek siswa $61 \%$. Peneliti menyimpulkan permasalahan-permasalahan yang ditemukan observer pada pelaksanaan proses pembelajaran, sehingga pelaksanaan proses pembelajaran kurang sesuai dengan 
yang diharapkan. Seperti (1) pada saat pelaksanaan proses pembelajaran masih terlihat pemisahan antara mata pelajaran, (2) guru kurang memotivasi siswa dalam menggali informasi melalui pengamatan yang dilakukan siswa, sehingga siswa kurang fokus terhadap topik pembelajaran, (3) guru kurang memberikan kesempatan pada siswa untuk melatih kemampuan dalam komunikasi seperti bertanya, sehingga pembelajaran terfokus pada guru (teacher center), (4) guru kurang memberikan dorongan kepada siswa untuk mengumpulkan informasi dari apa yang sudah diamati, sehingga siswa kurang aktif dalam belajar (5) guru kurang memberi dorongan siswa dalam mengolah informasi dari apa yang sudah diamati, sehingga siswa kurang paham dalam pembelajaran (6) guru belum sepenuhnya memberi kesempatan kepada siswa untuk mengomunikasikan/ menyimpulkan apa yang telah dipelajari siswa, sehingga pembelajaran terfokus dari apa yang hanya diberikan guru. Maka dari temuan permasalahan itu, peneliti berkesimpulan bahwasanya proses pembelajaran berbasis ilmiah belumlah optimal dalam pelaksanaannya.

Apabila hal di atas dibiarkan maka dapat mengakibatkan dampak seperti: (1) siswa kurang memahami konsep pembelajaran yang diajarkan oleh guru, pembelajaran kurang mendorong terjadinya peningkatan kemampuan berfikir siswa, (2) siswa kurang terlatih dalam bertanya pada saat proses pembelajaran berlangsung, (3) siswa menjadi kurang antusias untuk mencoba mengkonstruk informasi dari materi/ media yang diberikan guru, (4) siswa terlihat kurang paham terhadap materi yang disampaikan guru karena kurangnya kegiatan menyimpulkan materi diakhir proses pembelajaran.

Berdasarkan hal tersebut penulis akan meningkatkan proses pembelajaran dengan menggunakan pendekatan saintifik. Karna pendekatan saintifik memiliki keunggulan yang mendukung tujuan pembelajaran kurikulum 2013. Dimana pembelajaran dengan proses saintifik merupakan pembelajaran yang menuntut siswa berfikir secara sistematis dan kritis dalam upaya memecahkan masalah yang penyelesaiannya tidak mudah dilihat (Barringer, et al 2010). Weinbaum, et al. (2004) juga menyatakan bahwa pembelajaran dengan konsep saintifik merupakan proses membangun makna dari informasi baru dengan menggunakan kerangka kerja konseptual. Proses memahami informasi factual dalam kerangka konseptual memungkinkan siswa untuk mengambil, mengatur, dan mempertahankan informasi baru tersebut. Ketika informasi factual dipelajari tanpa kerangka kerja konseptual yang jelas, berbagai informasi yang dipelajari tersebut biasanya dilupakan dalam waktu singkat. Hosnan (2014) menambahkan, pendekatan saintifik adalah proses pembelajaran yang dirancang sedemikian rupa agar siswa secara aktif mengonstruksi konsep, hukum atau prinsip melalui tahapan-tahapan mengamati (untuk mengidentifikasi atau menemukan masalah), merumuskan masalah, mengajukan atau merumuskan hipotesis, mengumpulkan data dengan berbagai teknik, menganalisis data, menarik kesimpulan dan mengomunikasikan konsep, hukum atau prinsip yang ditemukan. Sebagaimana studi terdahulu yang dilakukan Fatmawati (2019) dengan hasil penilitian bahwa proses pembelajaran dapat meningkat dengan pendekatan saintifik di sekolah dasar. Begitu juga menurut Iasha (2018) yang memperoleh hasil penelitian yang sama, bahwa adanya peningkatan proses pembelajaran yang menggunakan pendekatan saintifik di sekolah dasar.

Berdasarkan uraian dari latar belakang di atas. Maka, secara umum masalah dalam penelitian ini adalah "Bagaimanakah peningkatan proses pembelajaran tematik terpadu menggunakan pendekatan saintifik siswa kelas III Sekolah Dasar?" Rumusan masalah secara khusus yaitu "Bagaimana rencana pelaksanaan pembelajaran dan pelaksanaan pembelajaran tematik terpadu untuk meningkatkan proses pembelajaran 
dengan menggunakan pendekatan saintifik siswa kelas III Sekolah Dasar?"

Sesuai dengan rumusan masalah yang telah dipaparkan maka tujuan penelitian secara umum adalah untuk mendeskripsikan peningkatan proses pembelajaran tematik terpadu menggunakan pendekatan saintifik siswa kelas III Sekolah Dasar. Tujuan khusus penelitian adalah untuk mendeskripsikan Rencana pelaksanaan pembelajaran tematik terpadu dan Pelaksanaan pembelajaran tematik terpadu untuk meningkatkan proses pembelajaran dengan menggunakan pendekatan saintifik siswa kelas III Sekolah Dasar.

\section{METODE PENELITIAN}

Jenis penelitian ini adalah penelitian tindakan kelas, penelitian yang dilakukan di dalam kelas dengan tujuan untuk memperbaiki atau meningkatkan hasil belajar siswa dan proses pembelajaran agar berjalan dengan baik. Wijaya dan Dedi (2011) menjelaskan bahwa Penelitian Tindakan Kelas adalah penelitian yang dilakukan oleh guru kelasnya sendiri dengan cara merencanakan, melaksanakan, merefleksikan tindakan secara kolaboratif dengan tujuan memperbaiki kinerjanya sebagai guru, sehingga hasil belajar siswa dapat meningkat.

Penelitian ini dilaksanakan di kelas III Sekolah Dasar. Penelitian ini dilaksanakan di semester II tahun ajaran 2020/2021. Penelitian ini dilakukan dalam dua siklus. Siklus I dilaksanakan dua kali pertemuan. Siklus II dilaksanakan satu kali pertemuan.

Subjek dalam penelitian ini adalah siswa semester II kelas III Sekolah Dasar. Dengan jumlah siswa sebanyak 22 orang, yang terdiri dari 14 orang siswa laki-laki dan 8 orang siswa perempuan. Di samping itu, penulis sebagai praktisi (guru) pada kelas III Sekolah Dasar dan dua orang pengamat (observer) yaitu guru kelas dan teman sejawat.

Sebelum melakukan penelitian, peneliti terlebih dahulu melakukan studi pendahuluan, berupa observasi terhadap proses pembelajaran di kelas III Sekolah Dasar. Hal ini bertujuan untuk mengetahui permasalahan yang terdapat pada pembelajaran tematik terpadu. Studi pendahuluan dilakukan untuk mengamati proses pembelajaran di kelas dan diskusi dengan guru tentang pembelajaran yang terjadi, dari studi pendahuluan maka akan terlihat masalah yang akan diteliti. Kemudian permasalahan tersebut diatasi dengan penelitian tindakan kelas melalui prosedur yang terdiri dari beberapa tahapan, yaitu: perencanaan, pelaksanaan, pengamatan, dan tahap refleksi. Intrumen Penelitian Instrumen yang akan digunakan dalam penelitian ini yaitu lembar observasi, tes dan non tes, kemudian dokumentasi. Lembar Observasi, dilakukan untuk mengamati proses pembelajaran yang berlangsung dengan berpedoman pada lembar observasi yang telah disediakan untuk mengamati aktivitas guru maupun siswa pada saat berlangsungnya pembelajaran proses pembelajaran tematik terpadu dengan menggunakan pendekatan saintifik. Tes adalah alat yang digunakan untuk melihat hasil belajar setiap akhir tindakan setelah proses pembelajaran dengan menggunakan pendekatan saintifik. Non tes digunakan untuk mengukur dan memperoleh data tentang sikap dan keterampilan siswa dalam pembelajaran tematik terpadu dengan menggunakan pendekatan saintifik.

Data yang diperoleh dalam penelitian dianalisis dengan menggunakan analisis data kualitatif dan kuantitatif yang dikemukakan oleh Miles dan Huberham (dalam Sugiono, 2009) yakni, Analisis data yang dimulai dengan menelaah sejak pengumpulan data sampai seluruh data terkumpul. Data tersebut direduksi berdasarkan masalah yang diteliti, diikuti penyajian data yang berakhir pengumpulan data atau verifikasi. Tahap analisis yang demikian dilakukan berulangulang begitu data selesai dikumpulkan setiap tahap pengumpulan data dalam setiap tindakan. Untuk menghitung penilaian persentase pencapaian yang dikemukakan oleh 
Purwanto (2012:103) dengan menggunakan rumus:

$\mathrm{NP}=\mathrm{R} / \mathrm{SM} \times 100 \%$

Keterangan:

$\mathrm{NP}=$ nilai persen yang dicari

$$
\begin{array}{ll}
\underset{\text { siswa }}{\mathrm{R}} & =\text { skor mentah yang diperoleh } \\
\mathrm{SM} & =\text { skor maksimum }
\end{array}
$$

Dengan kriteria taraf keberhasilannya dapat ditentukan sebagai berikut:

Tabel 1. Kriteria Taraf Keberhasilan

\begin{tabular}{ll}
\hline \multicolumn{1}{c}{ Nilai } & \multicolumn{1}{c}{ Keterangan } \\
\hline $85<\mathrm{A} \leq 100$ & A (sangat baik) \\
$75<\mathrm{B} \leq 85$ & B (baik) \\
$60<\mathrm{C} \leq 75$ & C (cukup) \\
$55 \leq 59$ & D (kurang) \\
$\leq 54$ & TL (kurang sekali) \\
\hline
\end{tabular}

\section{HASIL DAN PEMBAHASAN \\ HASIL Siklus I \\ Perencanaan}

Rancangan pembelajaran disusun secara kolaboratif antara peneliti dengan guru kelas III Sekolah Dasar. Sebelum RPP disusun, peneliti dan guru kelas terlebih dahulu menganalisis kompetensi- kompetensi dasar yang terkait. Pada Siklus I pertemuan I ini akan membahas tema 6 (Energi dan Perubahannya), subtema 1 (Sumber Energi) pada pembelajaran 1, dengan muatan pelajaran yang terkait yaitu Bahasa Indonesia, SBdP dan Matematika. Sedangkan siklus I pertemuan II membahas tema 6 (Energi dan Perubahannya), subtema 2 (Perubahan Energi) pada pembelajaran 1, dengan muatan pelajaran Bahasa Indonesia, SBdP, dan Matematika. Dengan menggunakan pendekatan saintifik sesuai dengan langkah-langkah menuruut Kemendikbud (2014:19) yaitu: (1) mengamati

(2) menanya, (3) mengumpulkan informasi/eksperimen,

mengasosiasikan/mengolah informasi,

mengkomunikasikan.

\section{Pelaksanaan}

Pelaksanaan Siklus I proses pelaksanaan tindakan dengan menggunakan pendekatan saintifik sesuai dengan langkahlangkah menuruut Kemendikbud (2014) yaitu:
(1) mengamati
(2) menanya, mengumpulkan informasi/eksperimen, mengasosiasikan/mengolah informasi, (5) mengkomunikasikan. Kegiatan yang dilakukan adalah: Mengamati, meliputi mengamati gambar, video, teks bacaan, demonstrasi, lingkungan sekitar, penjelasan guru dan sebagainya. Menanya, meliputi bertanya mengenai gambar, video, teks bacaan, demonstrasi, lingkungan sekitar, penjelasan guru dan sebagainya. Mengumpulkan informasi, meliputi menemukan informasi dari kegiatan mengamati, bertanya jawab, teks bacaan. Mengolah informasi, meliputi menyimpulkan hasil pengamatan dan tanya jawab, mengerjakan LKPD, dan sebagainya. Mengomunikasikan, meliputi menyampaikan pertanyaan, menyampaikan opini, menyampaikan hasil LKPD, dan lainnya.

\section{Pengamatan}

Pengamatan dilakukan setiap siklus I dimana hasil yang diperoleh yaitu lembar penilaian RPP, lembar pengamatan proses pelaksanaan pembelajaran tematik terpadu dengan menggunakan pendekatan saintifik dari aktivitas guru dan aktivitas siswa yang diisi oleh observer, rencana pelaksanaan pembelajaran pada siklus I memperoleh persentase 98\% (A), maka penilaian aktivitas guru dalam melaksanakan pembelajaran pada siklus I diperoleh persentase $80 \%$ (B), dan penilaian aktivitas siswa dalam melaksanakan pembelajaran siklus I diperoleh persentase $51.59 \%(\mathrm{TL})$ 
Tabel 2. Tabel Hasil Penelitian Siklus I

\begin{tabular}{lll}
\hline No. & Aspek yang dinilai & Penilaian \\
\hline 1. & RPP & $98 \%$ \\
2. & Aspek guru & $80 \%$ \\
3. & Aspek siswa & $51.59 \%$ \\
\hline
\end{tabular}

Siklus II

\section{Perencanaan}

Perencanaan RPP siklus II telah diperbaiki berdasarkan hasil refleksi siklus I. Sehingga pengamatan terhadap RPP pada siklus I pertemuan II diperoleh $100 \%$ (A). Hal ini menunjukkan bahwa kemampuan guru dalam merencanakan pembelajaran pendekatan saintifik memiliki klasifikasi sangat baik.

\section{Pelaksanaan}

Pelaksanaan Siklus II proses pelaksanaan tindakan ditingkatkan berdasarkan hasil refleksi pada siklus I.

Dari observasi pelaksanaan kegiatan guru pada penelitian siklus II dapat dilihat hasil observasi kegiatan guru diperoleh persentase 95\% dengan kualifikasi sangat baik. Dan kegiatan siswa diperoleh persentase $86,59 \%$ dengan kualifikasi sangat baik.

Tabel 3. Tabel Hasil Penelitian Siklus II

\begin{tabular}{lll}
\hline No. & Aspek yang dinilai & Penilaian \\
\hline 1. & RPP & $100 \%$ \\
2. & Aspek guru & $95 \%$ \\
3. & Aspek siswa & $86.59 \%$ \\
\hline
\end{tabular}

\section{Refleksi}

Berdasarkan hasil pengamatan RPP, aspek guru dan aspek siswa yang telah mencapai target. Maka penelitian tidak dilanjutkan pada siklus berikutnya.

Dari hasil penelitian ini, terlihat bahwa ada peningkatan dari kegiatan mengajar guru pada tahap pelaksanaan mulai dari siklus I sampai siklus II. Sebagaimana studi terdahulu yang dilakukan Fatmawati (2019) dengan hasil penilitian bahwa proses pembelajaran dapat meningkat dengan pendekatan saintifik di sekolah dasar. Begitu juga menurut Iasha (2018) yang memperoleh hasil penelitian yang sama, bahwa adanya peningkatan proses pembelajaran yang menggunakan pendekatan saintifik di sekolah dasar.

\section{PEMBAHASAN}

Berawal dari ditemukan permasalahan dalam proses pembelajaran di kelas III Sekolah Dasar yaitu guru kurang memotivasi siswa dalam menggali informasi melalui pengamatan yang dilakukan siswa, guru kurang memberikan kesempatan pada siswa untuk melatih kemampuan dalam komunikasi seperti bertanya, sehingga pembelajaran terfokus pada guru (teacher center), guru kurang memberikan dorongan kepada siswa untuk mengumpulkan informasi dari apa yang sudah diamati, guru kurang memberi dorongan siswa dalam mengolah informasi dari apa yang sudah diamati, guru belum sepenuhnya memberi kesempatan kepada siswa untuk mengkomunikasikan/menyimpulkan apa yang telah dipelajari siswa. Dimana, hal tersebut membuat siswa kurang kritis dalam berfikir dan kurang aktif dalam melaksanakan proses pembelajaran. Oleh sebab itu, peneliti akan melakukan penelitian tindakan kelas, agar proses pembelajaran berjalan dengan optimal dengan menggunakan pendekatan saintifik. Dimana pembelajaran dengan proses saintifik merupakan pembelajaran yang menuntut siswa berfikir secara sistematis dan kritis dalam upaya memecahkan masalah yang penyelesaiannya tidak mudah dilihat (Barringer, et al 2010). Weinbaum, et al. (2004) juga menyatakan bahwa pembelajaran dengan konsep saintifik merupakan proses membangun makna dari informasi baru dengan menggunakan kerangka kerja konseptual. 
Proses memahami informasi factual dalam kerangka konseptual memungkinkan siswa untuk mengambil, mengatur, dan mempertahankan informasi baru tersebut. Hosnan (2014) menambahkan, pendekatan saintifik adalah proses pembelajaran yang dirancang sedemikian rupa agar siswa secara aktif mengonstruksi konsep, hukum atau prinsip melalui tahapan-tahapan mengamati (untuk mengidentifikasi atau menemukan masalah), merumuskan masalah, mengajukan atau merumuskan hipotesis, mengumpulkan data dengan berbagai teknik, menganalisis data, menarik kesimpulan dan mengomunikasikan konsep, hukum atau prinsip yang ditemukan.

Berdasarkan analisis data pada pengamatan RPP siklus I menunjukkan bahwa persentase pencapaian sebesar $98 \%$ dengan kualifikasi sangat baik (A). Pelaksanaan pembelajaran yang dilakukan pada siklus I pada aktivitas guru diperoleh persentase pencapaian $80 \%$ dengan kualifikasi baik (B). Sedangkan persentase pencapaian pendekatan saintifik dari aktivitas siswa 51.59 dengan kualifikasi kurang sekali (TL). Selanjutnya, pengamatan RPP pada siklus II persentase keberhasilannya $100 \%$ dengan kualifikasi sangat baik (A). Dan persentase pencapai dari aktivitas guru yaitu $95 \%$ dengan kualifikasi sangat baik (A). Sedangkan persentase pencapaian dari aktivitas siswa $86,59 \%$ dengan kualifikasi sangat baik (A).

Penelitian ini sejalan dengan penelitian yang dilakukan oleh Fatmawati dengan judul penelitian "Peningkatan Proses Pembelajaran Tematik Terpadu Menggunakan Pendekatan Saintifik di Kelas I Sekolah Dasar". Persamaan dalam penelitian ini yaitu meneliti proses pembelajatan tematik terpadu dan menggunakan pendekatan saintifik. Hasil siklus I dengan rata-rata $78 \%$ dan meningkat pada siklus II dengan rata-rata $92 \%$. Begitu juga sejalan dengan penelitian Iasha dengan judul "Peningkatan Proses Pembelajaran Tematik Terpadu Menggunakan Pendekatan Scientifik Sekolah Dasar". Persamaan dalam penelitian ini yaitu meneliti proses pembelajatan tematik terpadu dan menggunakan pendekatan saintifik. Hasil siklus I dengan rata-rata $76.67 \%$ dan meningkat pada siklus II dengan rata-rata $93.33 \%$.

Berdasarkan hasil penelitian dan penelitian sebelumnya, maka pelaksanaan pendekatan saintifik telah berhasil meningkatkan proses pembelajaran siswa di kelas III Sekolah Dasar.

\section{SIMPULAN DAN REKOMENDASI}

Berdasarkan hasil analisis data proses pembelajaran menggunakan pendekatan saintifik siswa kelas III Sekolah Dasar mengalami peningkatan baik dari segi perencanaan dan pelaksanaan.

\section{Saran}

Berdasarkan penelitian ini, peneliti memberikan saran bahwa pendekatan saintifik dapat digunakan untuk muatan pelajaran yang lainnya., yang membuat siswa menjadi lebih kritis dan aktik dalam proses pembelajaran.

\section{DAFTAR PUSTAKA}

Barringer, M.-D., Pohlman, C., \& Robinson, M. (2010). Schools For All Kinds Of Minds: Boosting Student Success By Embracing Learning Variation. John Wiley \& Sons.

Fatmawati. (2019). Peningkatan Proses Pembelajaran Tematik Terpadu Menggunakan Pendekatan Saintifik di Kelas I Sekolah Dasar. E-Jurnal Pembelajaran Inovasi, Jurnal Ilmiah Pendidikan Dasar: Vol 7, No. 6.

Hosnan. (2014). Pendekatan Saintifik dan Kontekstual dalam Pembelajaran Abad 21. Bogor: Ghalia Indonesia.

Iasha. (2018). Peningkatan Proses Pembelajaran Tematik Terpadu Menggunakan Pendekatan Scientifik Sekolah Dasar. Jurnal Pendidikan Dasar:: Vol 2, No. 1. 


\section{PRIMARY: JURNAL PENDIDIKAN GURU SEKOLAH DASAR \\ VOLUME 10 NOMOR 4 AGUSTUS 2021 \\ ISSN : 2303-1514 | E-ISSN : 2598-5949 \\ DOI : http://dx.doi.org/10.33578/jpfkip.v10i4.8470 \\ https://primary.ejournal.unri.ac.id/index.php/JPFKIP}

Kemendikbud. (2014). Materi Pelatihan Guru Implementasi Kurikulum 2013. Jakarta: Kemendikbud

Pahrudin, Agus dan Dona.D.P. (2019). Pendekatan Saintifik dalam Implementasi Kurikulum 2013 dan Dampaknya Terhadap Kualitas Proses dan Hasil Pembelajaran Pada MAN Di Provinsi Lampung. Lampung :Pustaka Ali Imron.

Purwanto. (2012). Evaluasi hasil belajar. Yogyakarta. Pustaka Belajar.
Rusman. (2015). Pembelajaran Tematik Terpadu Teori, Praktik dan Penilaian. Jakarta Rajawali Press

Sugiyono. (2011). Metode Penelitian Kuantitatif, Kualitatif, Dan Kombinasi (Mixed Methods). Bandung. Alfabeta.

Weinbaum, A., Et.Al. (2004). Teaching As Inquiry: Asking Hard Questions To Improve Practice And Student Achievement. Teaching College Press, New York.

Wijaya dan Dedi. (2011). Penelitian Tindakan Kelas. Jakarta:Indeks 